way of knowing that sperms are normal. Without exception, when I inform prospective A.I.D. recipients tha tonly proved donor semen will be used they are that much more reassured.

Frozen Semen.-The fact that good results are obtained in cows with semen frozen by liquid nitrogen has little bearing on human A.I.D. A farmer will have no second thoughts about killing a deformed calf. From my extensive reading of the American use of frozen semen I regard their apparently successful results-up to $70 \%$-with great suspicion. No British doctor who practises A.I.D. has admitted a success rate of much greater than $50 \%$ using fresh semen. I have studied the method of using frozen $\mathrm{CO}_{2}$ for freezing semen used by Dr. R. G. Bunge of Iowa (personal communication), who also claims excellent results, and found a considerable increase in immobility and frag mentation of sperms after defreezing. No one knows the effect on the genetic materia in the frozen sperm, and there is no method of detecting any damage. The great majority of my patients who have been successfully inseminated by donor have resisted any type of follow-up. They want to forget the husband's infertility, and this reaction is understandable. Therefore I consider it extremely difficult for any organized scientific investigation to determine, with reasonable accuracy, the effects of using frozen semen over a sufficiently long period of time to produce statistically significant results proving or disproving the harmlessness of this method. In my view the demand for A.I.D. is insufficient to warrant the use of frozen semen, with all the hazards that this may entail.

Semen Banks.-It is difficult to see how anyone with personal experience of A.I.D. could suggest the setting up of semen banks. How could one confirm, in some way similar to the cross-matching of blood before transfusion, that the semen in tube XYZ was in fact the semen from a fair-haired white man (or dark-haired black man) before using it for insemination? As one cannot confirm whose semen is in the tube, whose responsibility will it be if a white-skinned mother gives birth to a black baby or a West Indian mother to a white baby?

Confidentiality.-What can happen in an N.H.S. hospital concerning confidentiality is illustrated by the experience of an unmarried woman of my acquaintance who was admitted for termination of pregnancy. She was assured by the gynaecologist that the abortion would be conducted under completely confidential conditions but when her mother arrived at reception and inquired which ward her daughter was in, she was told by the porter, "You'll find your lass in the abortion ward, darling."

Public Attitudes to A.I.D.-If the "climate of opinion" has changed towards A.I.D., then the extent of the change may be less than the panel is aware. Last year the editor of the Daily Telegraph would not allow my advertisement for a suitable Hindu-Sikh donor to be placed in the personal column. This month the editor of the fewish Chronicle has refused a similar advertisement for a Jewish donor.

To summarize, it would appear that the panel was very poorly informed as to the problems associated with A.I.D.-I am, etc.,

JOHN SLOME

\section{Achilles Tendon Reflex in Hypothermia and Myxoedema}

SIR,-During the relaxation phase of a tendon reflex the muscle is electrically silent. "Brisk relaxation" of a muscle therefore cannot be caused by a lesion of the central nervous system as suggested by Dr. D. Maclean and others (14 April, p. 87). A more reasonable conclusion would be that hypothermia and hypothyroidism do not invariably delay muscle relaxation.-I am, etc.,

The London Hospital,

D. L. MCLeLlan

London E.1

\section{Malignant Hyperpyrexia}

SIR,-It is interesting to see in the letter from Dr. M. A. Denborough and others (24 March, p. 738) that their earliest recorded case of death from malignant hyperpyrexia occurred in 1921. Britt and Kalow mentioned another fatal case of malignant hyperpyrexia occurring in 1922. Both cases, of course, $\alpha$ curred well before the introduction of succinyloholine and halothane. These agents cannot therefore be specifically incriminated, as suggested by Dr. C. Langton Hewer (24 March, p. 738). Ether, cyclopropane, trichloroethylene, and methoxyflurane have probably also been responsible for inducing the syndrome, ${ }^{1}$ though it is rarely possible to be absolutely sure of this because of the multiplicity of drugs commonly used during anaesthetic procedures. Ether may well be less potent in this respect than halothane; it is less potent in unooupling oxidative phosphorylation in liver mitochondria, the relative potencies being related to the partition coefficient of the agents between lipids and water. ${ }^{2}$

Dr. Hewer is, I am sure, quite correct in maintaining the separation of malignant hyperpyrexia from the syndrome of late ether convulsions. In fact he made an early contribution to the discussion of the aetiology of ether convulsions. ${ }^{3}$ It is, however, unlikely that ether convulsions had a single cause. The earlier literature on operative and postoperative hyperpyrexia and fits contained much uncertainty about the possible roles of pre-existing hyperpyrexia, hot operating theatres, excessive draping of the patient, and atropine premedication. Agents other than ether were at times responsible for identical convulsions and hyperpyrexia.

The major contribution of Dr. Denborough and his colleagues ${ }^{5}$ was the recognition of a family of patients developing fatal hyperpyrexia with anaesthesia. ${ }^{5}$ Sporadic cases, however, do occur, ${ }^{6}$ and I agree with the suggestion that some of the cases recorded in the earlier literature as late ether convulsions may well have been suffering from malignant hyperpyrexia. If ether is a less potent agent, which induces malignant hyperpyrexic reactions less quickly than halothane and succinylcholine, then one may perhaps accept the six cases reported by Guedel ${ }^{7}$ as coming into the category of malignant hyperpyrexia. Certainly it is not easy to see from what they suffered if not malignant hyperpyrexia, and Britt and Kalow, 1 who have extensively reviewed the literature, accepted these as cases of malignant hyperpyrexia. Nevertheless, I agree that it is impossible to be certain of the diagnosis without the confirmation of a positive family history.
More important than this discussion, however, is the elucidation of the mechanism underlying the malignant hyperpyrexia reaction. As mentioned previously, ${ }^{89}$ contrary to the findings of Ellis et al. ${ }^{10}$ and of Dr. Denborough and his colleagues (3 February, p. 272), we found no histological abnormality in muscle biopsy specimens from six individuals, all of whom had raised serum creatine kinase levels and were relatives of patients who had suffered from malignant hyperpyrexia. In particular "moth-eaten fibres," cores, and pseudo-cores were not present. We did not find that halothane and succinylcholine invariably induced contracture in vitro in susceptible muscle, which again differed from the findings of Ellis et al. ${ }^{10}$ Our physiological ${ }^{8}$ and biochemical ${ }^{11}$ studies failed to elucidate the underlying pathogenetic mechanism. Further studies of the muscle biochemistry and of the part played by thyroid hormones ${ }^{12}$ are therefore awaited with great interest.-I am, etc.,

Newcastle General Hospital,

W. G. BRADLEY pon Tyne

1 Britt, B. A., and aKlow, W., Canadain Anaesthetists' Society fournal, 1970, 17, 293.
nodgrass, P. J., and Piras, M. M., Biochemistry, 1966, 5. 1140., and Piras, M. M., Biochemistry,
Hewer, C. L., British Medical Fournal, 1930,

2. 80, R. C., British Medical fournal, 1954, 2, 1526 .

Denborough, M. A., Forster, J. F. A., Lovell,
R. R. H., Maplestone, P. A., and Villiers, J. D., British fournal of Anaesthesia, 1962, 34, 395. King, J. O., Denborough, M. A., and Zapf, P. W. Lancet, 1972, 1. 365 .

Guedel, A. E., Inhalation Anaesthesia, p. 133 New York, Macmillan, 1937. Bradley, W. G., Ward, M., Murchison, D., Hall L., and Woolf, N., Proceedings of

Bradley, of Medicine, 1973, 66, 67. D., British Medical fournal, 1972, 4, 108.

Elliedical Fournal, 1972, 4 , 108 . et al., British Medical fournal, 1972 3,559.

Pennington, R. J. T., and Worsfold, M., Proceedings of the Royal Society of Medicine, 1973 66,69 .

12 Lister, D., British Medical fournal, 1973, 1, 208.

\section{Treatment of Depression in General Practice}

SIR,-The paper by Dr. D. A. W. Johnson (7 April, p. 18) requires comment because it shows two serious deficiencies. In the first place the validity of many of his data is questionable owing to inadequacies of method. In the second place, even if accepted at face value, his results fail to justify his harsh criticism of his general practitioner colleagues.

Dr. Johnson fails to emphasize the accuracy of the G.P.s' diagnosis of depression. That 73 patients out of 91 interviewed by him satisfied his criteria is remarkable in view of the frequently repeated assertion that the G.P. does not recognize depression.

Dr. Johnson then criticized G.P. treatment in terms of drug therapy, psychotherapy, and the involvement of the social agencies. Seven days after the initial interview with the G.P. $72 \%$ of the patients were on the right drug in the right dosage, and of the remaining $28 \%$ the vast majority were on the right drug in what he considered to be inadequate dosage. Dr. Johnson's criticism is that this is not the best treatment, but he has no controls and cannot demonstrate better treatment apart from an assumption that he could provide it. Drug defaulting is a major problem, but in the absence of controls we would suggest that it could be an even larger 